\title{
Effects of lanthanum on the antioxidant capacity of chloroplasts and chlorophyll fluorescence parameters of maize seedlings under chromium stress
}

\author{
H. DAI ${ }^{*, * *}$ and C. SHAN ${ }^{*, * *,+}$ \\ Henan Institute of Science and Technology, Xinxiang, 453003 China* $^{*}$ \\ Collaborative Innovation Center of Modern Biological Breeding, Henan Province, Xinxiang 453003, China**
}

\begin{abstract}
Effects of lanthanum chloride $\left(\mathrm{LaCl}_{3}\right)$ on chromium tolerance of maize were investigated at chloroplast level. The results showed that $\mathrm{Cr}$ stress significantly increased activities of ascorbate peroxidase, glutathione reductase, monodehydroascorbate reductase, dehydroascorbate reductase, superoxide dismutase, and glutathione peroxidase, nonphotochemical quenching, malondialdehyde (MDA) and hydrogen peroxide contents, but significantly reduced the ratios of reduced ascorbate to dehydroascorbate and reduced glutathione to oxidized glutathione, the contents of chlorophyll and carotenoids, maximum photochemical efficiency of PSII, photochemical quenching, quantum efficiency of PSII photochemistry, net photosynthetic rate, plant height and biomass, compared with control. Compared to $\mathrm{Cr}$ stress alone, $\mathrm{LaCl}_{3}$ significantly reduced $\mathrm{MDA}$ and $\mathrm{H}_{2} \mathrm{O}_{2}$ contents and increased other indicators under $\mathrm{Cr}$ stress. $\mathrm{LaCl}_{3}$ alone also enhanced above indicators except MDA and $\mathrm{H}_{2} \mathrm{O}_{2}$, compared with control. Our results suggested that $\mathrm{LaCl}_{3}$ improved the $\mathrm{Cr}$ tolerance of maize crops by upregulating the antioxidant capacity and the function of chloroplasts.
\end{abstract}

Additional key words: antioxidant system; chlorophyll fluorescence; chromium injury; lanthanum chloride; plastid; Zea mays.

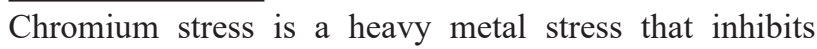
the growth and development of plants (Ma et al. 2016). $\mathrm{Cr}$ stress usually induces the accumulation of reactive oxygen species (ROS), which induces peroxidative damage to plants (Mahmud et al. 2017). Chloroplast is an important cell compartment for its basic role in photosynthesis. However, chloroplast is highly vulnerable to peroxidative damage induced by stresses. Fortunately, chloroplast has developed an intricate antioxidant defense system to protect itself against the harmful effects of peroxidative damage, including antioxidative enzymes and nonenzymatic compounds. The antioxidant enzymes mainly include superoxide dismutase (SOD), glutathione peroxidase (GPX), and ascorbate peroxidase (APX), etc. Nonenzymatic substances mainly include reduced ascorbate (AsA) and reduced glutathione (GSH), etc.

Lanthanum ( $\mathrm{La})$ is an important rare earth element, which can promote root organogenesis (Guo et al. 2012), mediate secondary metabolism synthesis (Zhou et al. 2012), and promote nitrogen metabolism (Huang et al. 2013), etc. Increasing evidence has proven that La could relieve peroxidative damage in plants under many stresses, including salt and water stresses (Zhang et al. 2006, Xu et al. 2007, Liu et al. 2016). However, little is known about antioxidative responses of plants to La under $\mathrm{Cr}$ stress at the chloroplast level. Thus, it is interesting to elucidate whether and how La regulates the antioxidant capacity in chloroplasts under $\mathrm{Cr}$ stress.

In this study, we investigated the effects of La on the activities of antioxidant enzymes, the ratios of reduced ascorbate to dehydroascorbate (AsA/DHA) and reduced glutathione to oxidized glutathione (GSH/GSSG), the contents of malondialdehyde (MDA) and $\mathrm{H}_{2} \mathrm{O}_{2}$ in the chloroplasts and chlorophyll fluorescence parameters of maize under Cr stress. The aim of this study was to elucidate the role of $\mathrm{La}$ in regulating $\mathrm{Cr}$ tolerance of maize and provide the theoretical basis for its application in

$\overline{\text { Received }} 8$ October 2017, accepted 22 June 2018.

${ }^{+}$Corresponding author; e-mail: shchjuan1978@aliyun.com

Abbreviations: APX - ascorbate peroxidase; AsA/DHA - the ratio of reduced ascorbate to dehydroascorbate; Car - carotenoids; Chl - chlorophyll; DAT - days of treatment; DHAR - dehydroascorbate reductase; $F_{v} / F_{m}$ - maximum photochemical efficiency of PSII; GPX - glutathione peroxidase; GR - glutathione reductase; GSH/GSSG - the ratio of reduced glutathione to oxidized glutathione; MDA - malondialdehyde; MDHAR - monodehydroascorbate reductase; $P_{\mathrm{N}}$ - net photosynthetic rate; $\mathrm{q}_{\mathrm{N}}$ - nonphotochemical quenching; $\mathrm{q}_{\mathrm{P}}$ - photochemical quenching; ROS - reactive oxygen species; SOD - superoxide dismutase; $\Phi_{\mathrm{PSII}}$ - effective quantum yield of PSII. Acknowledgements: This study was funded by Starting Fund for High-level Talents (Doctor) of Henan Institute of Science and Technology (2011010). 
promoting $\mathrm{Cr}$ tolerance of maize crops.

Seeds of maize (Zea mays, cv. Xindan 29) were germinated in Petri dishes with filter paper moistened by distilled water and grown in artificial climate chamber under a day/night temperature of $25 / 15^{\circ} \mathrm{C}$, PAR of 500 $\mu \operatorname{mol}\left(\right.$ photon) $\mathrm{m}^{-2} \mathrm{~s}^{-1}$, and a $10-\mathrm{h}$ photoperiod. When the first leaf was fully expanded, the seedlings were transferred into plastic boxes filled with half-strength Hoagland's solution and their roots were kept in dark. The half-strength Hoagland's solution was exchanged every two days. When the third leaf was fully expanded, the seedlings of uniform height were selected for all further experiments.

The suitable concentration of chromium chloride $\left[80 \mathrm{mg}\left(\mathrm{CrCl}_{3}\right) \mathrm{L}^{-1}\right]$ was selected from following concentrations including 40, 80, 120, and $160 \mathrm{mg}\left(\mathrm{CrCl}_{3}\right) \mathrm{L}^{-1}$. The obvious wilting phenomenon was observed in the seedlings treated by 120 and $160 \mathrm{mg}\left(\mathrm{CrCl}_{3}\right) \mathrm{L}^{-1}$ after $48 \mathrm{~h}$, while there was no obvious wilting in the seedlings treated by 40 and $80 \mathrm{mg}\left(\mathrm{CrCl}_{3}\right) \mathrm{L}^{-1}$ after $48 \mathrm{~h}$ (Figure $1 A$ ). Therefore, we selected $80 \mathrm{mg}\left(\mathrm{CrCl}_{3}\right) \mathrm{L}^{-1}$ as the suitable treatment concentration. After placing in distilled water for $12 \mathrm{~h}$, the roots were placed in beakers containing $100 \mathrm{ml}$ of $80 \mathrm{mg}\left(\mathrm{CrCl}_{3}\right) \mathrm{L}^{-1}$ for $48 \mathrm{~h}$ at $25^{\circ} \mathrm{C}$ with a continuous light intensity of $500 \mu \mathrm{mol}$ (photon) $\mathrm{m}^{-2} \mathrm{~s}^{-1}$. Beakers were wrapped with aluminium foil to keep roots in dark. In order to select a suitable concentration of

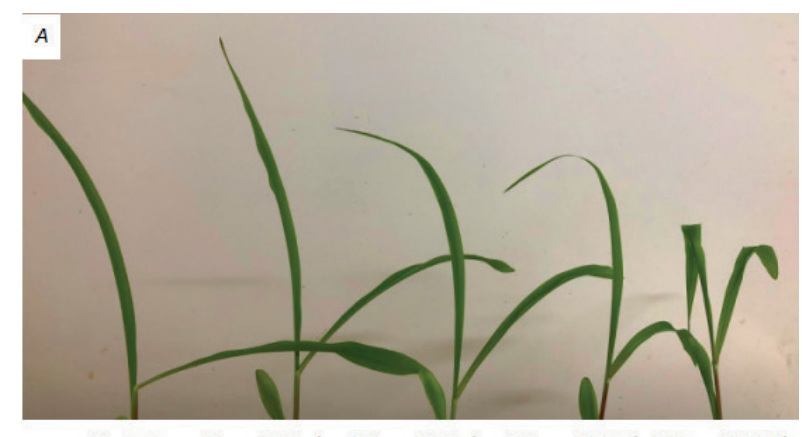

Control $\quad 40 \mathrm{mg}(\mathrm{Cr}) \mathrm{L}^{-1} \quad 80 \mathrm{mg}(\mathrm{Cr}) \mathrm{L}^{-1} \quad 120 \mathrm{mg}(\mathrm{Cr}) \mathrm{L}^{-1} \quad 140 \mathrm{mg}(\mathrm{Cr}) \mathrm{L}^{-1}$

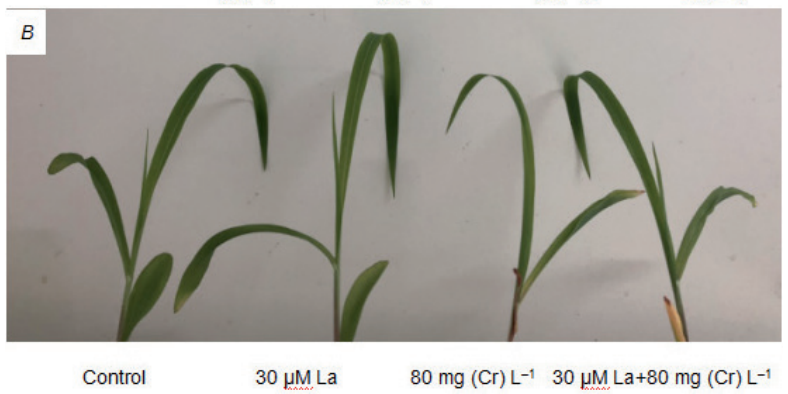

Fig. 1. Effects of different concentrations of $\mathrm{Cr}$ on the phenotype of maize seedlings under $\mathrm{Cr}$ stress after $48 \mathrm{~h}$ of treatment $(A)$ and the suitable concentration of $\mathrm{La}$ on the phenotype of maize seedlings under $\mathrm{Cr}$ stress after $7 \mathrm{~d}$ of treatment $(B)$. $(A)$ The plants were treated as follows: Control - half-strength Hoagland's solution with $\mathrm{CrCl}_{3}$ concentrations: $40,80,120,160 \mathrm{mg}(\mathrm{Cr}) \mathrm{L}^{-1}$. The plants were exposed to Cr stress for $48 \mathrm{~h}$. $(B)$ The plants were treated as follows: Control - half-strength Hoagland's solution with $\mathrm{CrCl}_{3}$ and $\mathrm{LaCl}_{3}: 30 \mu \mathrm{M} \mathrm{La}, 80 \mathrm{mg}(\mathrm{Cr}) \mathrm{L}^{-1}, 30 \mu \mathrm{M}$ $\mathrm{La}+80 \mathrm{mg}(\mathrm{Cr}) \mathrm{L}^{-1}$. The plants were pretreated with $\mathrm{LaCl}_{3}$ for $12 \mathrm{~h}$, and then exposed to $\mathrm{Cr}$ stress for $7 \mathrm{~d}$.
La, the effects of different concentrations of lanthanum chloride on the contents of MDA and $\mathrm{H}_{2} \mathrm{O}_{2}$ was tested, and then $30 \mu \mathrm{M} \mathrm{LaCl}_{3}$ was selected for the further experiment (Table 1S, supplement). To study the effect of $\mathrm{LaCl}_{3}$, plants were pretreated with $30 \mu \mathrm{M} \mathrm{LaCl}_{3}$ for $12 \mathrm{~h}$ and then exposed to $80 \mathrm{mg}\left(\mathrm{CrCl}_{3}\right) \mathrm{L}^{-1}$ or half-strength Hoagland's solution for $48 \mathrm{~h}$ under above conditions. Control plants were treated with half-strength Hoagland's solution alone. After treatment of $48 \mathrm{~h}$, the top full expanded leaves from different treatments were collected and frozen in liquid nitrogen, and then kept at $-80^{\circ} \mathrm{C}$ until analyses.

Intact chloroplasts were obtained from fresh maize leaves by density-gradient centrifugation in Percoll gradients according to the method of Wang et al. (2009). Each fresh sample of leaves $(50 \mathrm{~g})$ was homogenized in a blender with $200 \mathrm{ml}$ of ice-cold isolation buffer consisting of $330 \mathrm{mM}$ mannitol, $10 \mathrm{mM}$ ethylenediamine tetraacetic acid (EDTA), $5 \mathrm{mM} \mathrm{MgCl}$, $2 \mathrm{mM}$ sodium ascorbate, and $30 \mathrm{mM}$ 3-(N-morpholino) propanesulfonic acid (Mops) ( $\mathrm{pH}$ 7.6). The homogenates were filtered through four layers of cheesecloth and centrifuged at 4,000 $\times \mathrm{g}$ for $30 \mathrm{~s}$. The resulting crude chloroplast pellets were suspended in $5 \mathrm{ml}$ of suspension medium (330 mM mannitol, $2 \mathrm{mM}$ EDTA, and $50 \mathrm{mM}$ Mops $\mathrm{pH}$ 7.8). Chloroplast suspension $(2 \mathrm{ml})$ was layered on $50 \%$ Percoll and centrifugated at $5,000 \times g$ for $10 \mathrm{~min}$. The band near the bottom, containing intact chloroplasts, was diluted five times with the suspension medium to remove Percoll. The suspension was then centrifugated at $12,000 \times g$ for $10 \mathrm{~min}$. The pellets were resuspended in the same medium and used for further assays. All operations were performed at $0-4^{\circ} \mathrm{C}$.

The intact chloroplast samples were diluted ten folds with ice-cold $50 \mathrm{mM}$ potassium phosphate buffer ( $\mathrm{pH}$ 7.0) containing $1 \mathrm{mM}$ EDTA, $0.1 \%$ (w/v) CHAPSO, with the addition of $1 \mathrm{mM}$ ASA for APX and DHAR assay. Total SOD (EC 1.15.1.1) activity was assayed by monitoring the inhibition of photochemical reduction of nitroblue tetrazolium (NBT) according to the method of Giannopolitis and Ries (1977). The absorbance was recorded at $560 \mathrm{~nm}$ (TU-1810, Beijing Purkinje General Instrument Co.,Ltd., China), and one unit of SOD was defined as the amount of enzyme required to cause a $50 \%$ inhibition of NBT reduction. Glutathione peroxidase (GPX, EC 1.11.1.9) activity was measured according to He et al. (2006). One unit of GPX activity was defined as $1 \mu \mathrm{mol}(\mathrm{GSH}$ decreased) per min. Ascorbate peroxidase (APX, EC 1.11.1.11) activity was measured according to Nakano and Asada (1981) by monitoring the decrease in absorbance at $290 \mathrm{~nm}$ for $1 \mathrm{~min}$. One unit of enzyme was defined as the amount of APX catalyzing the oxidation of $1 \mu \mathrm{mol}$ (ascorbate) per min. Glutathione reductase (GR, EC 1.6.4.2) activity was monitored at $340 \mathrm{~nm}$ for 3 min (Grace and Logan 1996). One unit of GR activity was defined as the reduction of $1 \mu$ mol(NADPH) per min. Monodehydroascorbate reductase (MDHAR, EC 1.6.5.4) activity was assayed according to Miyake and Asada (1992) at $340 \mathrm{~nm}$ for $3 \mathrm{~min}$. One unit of MDHAR activity was defined as the amount of enzyme that oxidizes $1 \mu \mathrm{mol}(\mathrm{NADH})$ per min. Dehydroascorbate reductase (DHAR, EC 1.8.5.1) activity was measured 
according to Dalton et al. (1986) at $265 \mathrm{~nm}$ for $3 \mathrm{~min}$. One unit of DHAR activity was defined as the amount of enzyme that produces $1 \mu \mathrm{mol}(\mathrm{AsA})$ per min. The specific activities of above enzymes were expressed as Units $\mathrm{mg}^{-1}$ (protein). Protein concentration was measured by using bovine serum albumin as standard according to Bradford (1976).

The intact chloroplast samples purified from $2 \mathrm{~g}$ of leaves were homogenized with $5 \mathrm{ml}$ of 5\% ice-cold metaphosphoric acid. The homogenates were centrifuged at $4^{\circ} \mathrm{C}$ and $12,000 \times g$ for $20 \mathrm{~min}$. Then the resulting supernatants were immediately used for assay. AsA and dehydroascorbate (DHA) were measured according to Hodges et al. (1996). AsA/DHA was expressed as the ratio between the content of AsA and the content of DHA. Oxidized glutathione (GSSG) and GSH were measured according to Griffith (1980) GSSG was determined after removal of GSH by 2-vinylpyridine derivatization. GSH content was then estimated from the difference between total glutathione and GSSG. A standard curve prepared by using GSH and GSSG was used in the calculation of the amounts of total glutathione, GSH, and GSSG. GSH/ GSSG was expressed as the ratio between the content of GSH and the content of GSSG. Lipid peroxidation of chloroplasts was estimated by measuring MDA content according to the thiobarbituric acid (TBA) reaction (Heath and Packer 1968). $\mathrm{H}_{2} \mathrm{O}_{2}$ content was determined by measuring the absorption of titanium-hydroperoxide as described by Brennan and Frenkel (1977). The amount of $\mathrm{H}_{2} \mathrm{O}_{2}$ was calculated from the standardized $\mathrm{H}_{2} \mathrm{O}_{2}$ curve.

A Yaxin-1161G fluorometer (Yaxin, China) was used to measure the chlorophyll (Chl) fluorescence parameters from 10:00 to $12: 00 \mathrm{~h}$ after $2 \mathrm{~d}$ of treatment (DAT). For dark adaptation, the leaves were covered for $30 \mathrm{~min}$. Then Chl fluorescence parameters, such as maximum photochemical efficiency of PSII $\left(\mathrm{F}_{\mathrm{v}} / \mathrm{F}_{\mathrm{m}}\right)$, photochemical quenching $\left(\mathrm{q}_{\mathrm{P}}\right)$, nonphotochemical quenching $\left(\mathrm{q}_{\mathrm{N}}\right)$, and quantum efficiency of PSII photochemistry $\left(\Phi_{\mathrm{PSI}}\right)$, were measured by the fluorometer. Measurements were performed in a closed chamber under controlled conditions. Minimum fluorescence $\left(\mathrm{F}_{0}\right)$ was measured under a weak modulating radiation [0.5 $\mu$ mol(photon) $\mathrm{m}^{-2} \mathrm{~s}^{-1}$, and maximum fluorescence $\left(\mathrm{F}_{\mathrm{m}}\right)$ was induced by a saturating pulse of radiation [2400 $\mu \mathrm{mol}$ (photon) $\left.\mathrm{m}^{-2} \mathrm{~s}^{-1}\right]$. The photosynthetic rate $\left(P_{\mathrm{N}}\right)$ was measured by photosynthesis system (Licor-6400, USA) at an irradiance of $500 \mu \mathrm{mol}\left(\right.$ photon) $\mathrm{m}^{-2} \mathrm{~s}^{-1}$ and

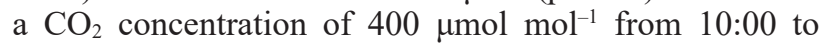
12:00 $\mathrm{h}$ after 2 DAT. After 7 DAT, plant height was measured by a ruler. Fresh masses of the seedlings of each treatment were recorded and then oven dried for $72 \mathrm{~h}$ at $80^{\circ} \mathrm{C}$. Dry mass of the seedlings of each treatment were then recorded.

The experimental design was a randomized complete block design with six replications. The results presented were means of six replications. Means were compared by one-way analysis of variance (ANOVA) and Duncan's multiple range test at the $5 \%$ level of significance.

Among different concentrations (10, 30, 50, and 100 $\mu \mathrm{M}), 30 \mu \mathrm{M} \mathrm{LaCl}{ }_{3}$ significantly decreased the contents of
MDA and $\mathrm{H}_{2} \mathrm{O}_{2}$ in the chloroplast of maize seedlings under $\mathrm{Cr}$ stress (Table $1 \mathrm{~S}$, supplement), which suggested that $30 \mu \mathrm{M} \mathrm{LaCl}{ }_{3}$ was the suitable concentration for this study.

Compared with control, $\mathrm{Cr}$ stress significantly increased the activities of APX, GR, DHAR, MDHAR, SOD, and GPX in chloroplasts (Table 1). Pretreatment with $\mathrm{LaCl}_{3}$ significantly increased the activities of above enzymes in chloroplasts under $\mathrm{Cr}$ stress, compared with $\mathrm{Cr}$ stress alone. After $48 \mathrm{~h}$ of treatment, $\mathrm{LaCl}_{3}$ increased the activities of APX, GR, DHAR, MDHAR, SOD, and GPX by $34.7,33.3,29.9,42.0,19.9$, and $31.4 \%$, respectively. Meanwhile, pretreatment with $\mathrm{LaCl}_{3}$ alone also significantly increased the activities of above enzymes in chloroplasts, compared with control. These results suggested that $\mathrm{LaCl}_{3}$ up-regulated the antioxidant metabolism in chloroplasts of maize by increasing the activities of above enzymes under Cr stress.

Compared with control, $\mathrm{Cr}$ stress significantly decreased the ratios of AsA/DHA and GSH/GSSG in chloroplasts (Table 1). Pretreatment with $\mathrm{LaCl}_{3}$ significantly elevated the ratios of AsA/DHA and GSH/GSSG under $\mathrm{Cr}$ stress, compared to $\mathrm{Cr}$ stress alone. After $48 \mathrm{~h}$ of treatment, $\mathrm{LaCl}_{3}$ increased the ratios of $\mathrm{AsA} / \mathrm{DHA}$ and GSH/GSSG by 22.4 and $34.5 \%$, respectively. Meanwhile, pretreatment with $\mathrm{LaCl}_{3}$ alone also signifi-cantly elevated the ratios of AsA/DHA and GSH/GSSG, compared with control. Above results suggested that pretreatment with $\mathrm{LaCl}_{3}$ regulated the redox state of the chloroplasts through AsA/DHA and GSH/GSSG under Cr stress.

$\mathrm{Cr}$ stress significantly declined the values of $\mathrm{F}_{\mathrm{v}} / \mathrm{F}_{\mathrm{m}}$, $\mathrm{q}_{\mathrm{P}}, \Phi_{\mathrm{PSII}}$, and $P_{\mathrm{N}}$ and increased $\mathrm{q}_{\mathrm{N}}$ after $48 \mathrm{~h}$ of treatment, compared with control (Table 1). Compared to $\mathrm{Cr}$ stress alone, pretreatment with $\mathrm{LaCl}_{3}$ followed by $\mathrm{Cr}$ stress significantly increased the values of $\mathrm{F}_{\mathrm{v}} / \mathrm{F}_{\mathrm{m}}, \mathrm{q}_{\mathrm{P}}, \mathrm{q}_{\mathrm{N}}, \Phi_{\mathrm{PSII}}$, and $P_{\mathrm{N}}$. After $48 \mathrm{~h}$ of treatment, $\mathrm{LaCl}_{3}$ increased $\mathrm{F}_{\mathrm{v}} / \mathrm{F}_{\mathrm{m}}$, $\mathrm{q}_{\mathrm{P}}, \mathrm{q}_{\mathrm{N}}, \Phi_{\mathrm{PSII}}$, and $P_{\mathrm{N}}$ by $23.1,45.4,20.9,35.0$, and $32.7 \%$, respectively. These results suggested that $\mathrm{LaCl}_{3}$ alleviated the negative effects of $\mathrm{Cr}$ stress on the photosynthetic apparatus of maize seedlings.

$\mathrm{Cr}$ stress significantly increased the contents of MDA and $\mathrm{H}_{2} \mathrm{O}_{2}$ in the chloroplasts, and decreased the contents of $\mathrm{Chl}$ and Car, plant height and plant biomass, compared with the control (Table 1). Pretreatment with $\mathrm{LaCl}_{3}$ decreased the contents of MDA and $\mathrm{H}_{2} \mathrm{O}_{2}$ in the chloroplasts by 30.4 and $37.4 \%$, respectively. Pretreatment with $\mathrm{LaCl}_{3}$ significantly increased the contents of $\mathrm{Chl}$ and Car, plant height and plant biomass by $17.0,40.0,11.5$, and $13.6 \%$, respectively. Meanwhile, pretreatment with $\mathrm{LaCl}_{3}$ alone also significantly decreased the contents of MDA and $\mathrm{H}_{2} \mathrm{O}_{2}$ in the chloroplasts, and increased the contents of $\mathrm{Chl}$ and Car, plant height, and plant biomass, compared with the control. Above results were also proved by the phenotype of different treatments at 7 DAT (Fig. 1B). These results suggested that pretreatment with $\mathrm{LaCl}_{3}$ has an important role in the acquisition of $\mathrm{Cr}$ tolerance of maize crops.

Many studies have proved that $\mathrm{Cr}$ stress induced oxidative damage in plants (Ma et al. 2016, Mahmud et al. 2017). In our study, an enhanced level of lipid peroxidation, as indicated by the contents of MDA and $\mathrm{H}_{2} \mathrm{O}_{2}$, was 
Table 1. Effects of $\mathrm{La}$ on the activities of ascorbate peroxidase (APX), glutathione reductase (GR), dehydroascorbate reductase (DHAR), monodehydroascorbate reductase (MDHAR), superoxide dismutase (SOD), and glutathione peroxidase (GPX), the ratios of reduced ascorbate to dehydroascorbate (AsA/DHA) and reduced glutathione to oxidized glutathione (GSH/GSSG), and the contents of malondialdehyde (MDA) and hydrogen peroxide $\left(\mathrm{H}_{2} \mathrm{O}_{2}\right)$ in chloroplasts, the chlorophyll fluorescence parameters, plant height and biomass, and the contents of chlorophyll (Chl) and carotenoids (Car) of maize seedlings under $\mathrm{Cr}$ stress. The plants were treated as follows: Control - half-strength Hoagland's solution; $\mathrm{La}-30 \mu \mathrm{M} \mathrm{LaCl}_{3} ; \mathrm{Cr}-80 \mathrm{mg}\left(\mathrm{CrCl}_{3}\right) \mathrm{L}^{-1} ; \mathrm{La}+\mathrm{Cr}-30 \mu \mathrm{M} \mathrm{LaCl}_{3}+80 \mathrm{mg}\left(\mathrm{CrCl}_{3}\right) \mathrm{L}^{-1}$. The plants were pre-treated with $\mathrm{LaCl}_{3}$ for $12 \mathrm{~h}$, and then exposed to $\mathrm{Cr}$ stress for $7 \mathrm{~d}$. Plant height and biomass were measured after $7 \mathrm{~d}$ of treatment, other parameters were all measured after $48 \mathrm{~h}$ of treatment. Values represent mean \pm standard deviations (SD), different small letters stand for significant difference between different treatments at $P<0.05$.

\begin{tabular}{|c|c|c|c|c|}
\hline Parameter & Control & $\mathrm{La}$ & $\mathrm{Cr}$ & $\mathrm{La}+\mathrm{Cr}$ \\
\hline APX [U mg ${ }^{-1}$ (protein) $]$ & $1.17 \pm 0.13^{\mathrm{d}}$ & $1.45 \pm 0.16^{\mathrm{c}}$ & $1.93 \pm 0.20^{\mathrm{b}}$ & $2.60 \pm 0.24^{\mathrm{a}}$ \\
\hline GR [U mg-1 (protein)] & $0.83 \pm 0.09^{\mathrm{d}}$ & $1.15 \pm 0.13^{\mathrm{c}}$ & $1.50 \pm 0.14^{\mathrm{b}}$ & $2.00 \pm 0.25^{\mathrm{a}}$ \\
\hline DHAR [U mg ${ }^{-1}$ (protein)] & $0.75 \pm 0.08^{\mathrm{d}}$ & $1.10 \pm 0.10^{c}$ & $1.44 \pm 0.15^{\mathrm{b}}$ & $1.87 \pm 0.19^{\mathrm{a}}$ \\
\hline MDHAR [U mg-(protein)] & $0.52 \pm 0.05^{\mathrm{d}}$ & $0.70 \pm 0.08^{c}$ & $1.00 \pm 0.11^{\mathrm{b}}$ & $1.42 \pm 0.15^{\mathrm{a}}$ \\
\hline 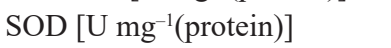 & $1.38 \pm 0.11^{\mathrm{c}}$ & $1.70 \pm 0.16^{\mathrm{b}}$ & $2.11 \pm 0.22^{b}$ & $2.53 \pm 0.27^{\mathrm{a}}$ \\
\hline GPX [U mg ${ }^{-1}$ (protein)] & $0.25 \pm 0.03^{\mathrm{c}}$ & $0.32 \pm 0.04^{\mathrm{b}}$ & $0.35 \pm 0.04^{\mathrm{b}}$ & $0.46 \pm 0.06^{\mathrm{a}}$ \\
\hline AsA/DHA & $20.20 \pm 1.84^{\mathrm{b}}$ & $23.17 \pm 2.11^{\mathrm{a}}$ & $14.63 \pm 1.58^{\mathrm{d}}$ & $17.90 \pm 1.93^{\circ}$ \\
\hline GSH/GSSG & $21.45 \pm 2.37^{\mathrm{b}}$ & $24.15 \pm 2.15^{\mathrm{a}}$ & $13.26 \pm 1.24^{\mathrm{d}}$ & $17.84 \pm 1.88^{\circ}$ \\
\hline $\operatorname{MDA}\left[\mathrm{nmol} \mathrm{g}^{-1}(\mathrm{FM})\right]$ & $4.33 \pm 0.50^{c}$ & $3.95 \pm 0.48^{c}$ & $13.11 \pm 1.44^{\mathrm{a}}$ & $9.12 \pm 1.03^{b}$ \\
\hline $\mathrm{H}_{2} \mathrm{O}_{2}\left[\mu \mathrm{mol} \mathrm{g}{ }^{-1}(\mathrm{FM})\right]$ & $0.40 \pm 0.05^{\mathrm{c}}$ & $0.35 \pm 0.06^{\mathrm{c}}$ & $1.95 \pm 0.22^{\mathrm{a}}$ & $1.22 \pm 0.14^{b}$ \\
\hline $\mathrm{F}_{\mathrm{v}} / \mathrm{F}_{\mathrm{m}}$ & $0.75 \pm 0.09^{b}$ & $0.85 \pm 0.11^{\mathrm{a}}$ & $0.52 \pm 0.07^{\mathrm{d}}$ & $0.64 \pm 0.08^{c}$ \\
\hline $\mathrm{q}_{\mathrm{P}}$ & $0.42 \pm 0.05^{\mathrm{b}}$ & $0.53 \pm 0.07^{\mathrm{a}}$ & $0.22 \pm 0.03^{\mathrm{d}}$ & $0.32 \pm 0.04^{\mathrm{c}}$ \\
\hline $\mathrm{q}_{\mathrm{N}}$ & $0.25 \pm 0.04^{\mathrm{d}}$ & $0.33 \pm 0.04^{\mathrm{c}}$ & $0.43 \pm 0.05^{\mathrm{b}}$ & $0.52 \pm 0.05^{\mathrm{a}}$ \\
\hline$\Phi_{\text {PSII }}$ & $0.35 \pm 0.04^{b}$ & $0.44 \pm 0.05^{\mathrm{a}}$ & $0.20 \pm 0.03^{\mathrm{d}}$ & $0.27 \pm 0.04^{\mathrm{c}}$ \\
\hline$P_{\mathrm{N}}\left[\mu \mathrm{mol} \mathrm{m} \mathrm{m}^{-2} \mathrm{~s}^{-1}\right]$ & $6.52 \pm 0.73^{b}$ & $7.50 \pm 0.88^{\mathrm{a}}$ & $3.85 \pm 0.51^{\mathrm{d}}$ & $5.11 \pm 0.58^{\mathrm{c}}$ \\
\hline $\operatorname{Car}\left[\mathrm{mg} \mathrm{g}^{-1}(\mathrm{FM})\right]$ & $0.66 \pm 0.07^{b}$ & $0.78 \pm 0.09^{\mathrm{a}}$ & $0.35 \pm 0.04^{\mathrm{d}}$ & $0.49 \pm 0.05^{\mathrm{c}}$ \\
\hline Chl $\left[\mathrm{mg} \mathrm{g}^{-1}(\mathrm{FM})\right]$ & $1.86 \pm 0.21^{\mathrm{b}}$ & $2.06 \pm 0.22^{\mathrm{a}}$ & $1.35 \pm 0.13^{\mathrm{d}}$ & $1.58 \pm 0.17^{\mathrm{c}}$ \\
\hline Plant height $(\mathrm{cm})$ & $17.00 \pm 1.82^{\mathrm{b}}$ & $18.90 \pm 2.00^{\mathrm{a}}$ & $13.00 \pm 1.46^{\mathrm{d}}$ & $14.50 \pm 1.30^{\circ}$ \\
\hline Plant biomass [g(FM) plant $\left.{ }^{-1}\right]$ & $1.14 \pm 0.13^{b}$ & $1.28 \pm 0.14^{\mathrm{a}}$ & $0.88 \pm 0.10^{\mathrm{d}}$ & $1.00 \pm 0.12^{\mathrm{c}}$ \\
\hline
\end{tabular}

observed in the chloroplasts of maize under Cr stress. This result suggested that $\mathrm{Cr}$ stress induced oxidative stress to the chloroplasts. To cope with Cr stress, the antioxidant capacity in the chloroplast of maize was up-regulated indicated by the activities of antioxidant enzymes APX, GR, DHAR, MDHAR, SOD, and GPX.

$\mathrm{La}$ is an important rare earth element. Increasing evidence has proven that La can relieve oxidative damage in plants exposed to a variety of stresses, including salt and osmotic stresses (Zhang et al. 2006, Xu et al. 2007). But, the antioxidative responses of chloroplast in plants to La under $\mathrm{Cr}$ stress are still unclear. In the present study, our results showed that La could up-regulate the activities of SOD, GPX, APX, GR, DHAR, and MDHAR and increase the ratios of AsA/DHA and GSH/GSSG in chloroplasts, which, in turn, improved the antioxidant capacity of chloroplasts. Meanwhile, our results showed that La could increase the values of $\mathrm{F}_{\mathrm{v}} / \mathrm{F}_{\mathrm{m}}, \mathrm{q}_{\mathrm{P}}, \mathrm{q}_{\mathrm{N}}$, and $\Phi_{\mathrm{PSII}}$ under $\mathrm{Cr}$ stress, which, in turn, improved the net photosynthetic rate. Above findings indicated that La could improve the function of photosynthetic apparatus in maize seedlings by increasing the antioxidant capacity in chloroplasts under Cr stress.

The redox state of plant cell is closely related to the ratios of AsA/DHA and GSH/GSSG. The ratios of AsA/ DHA and GSH/GSSG can be controlled by enzymes of a recycling pathway in plants, including APX, GR, DHAR and MDHAR. In present study, we found that $\mathrm{Cr}$ stress increased the activities of APX, GR, DHAR, and MDHAR in the chloroplasts of maize. However, our results showed that $\mathrm{Cr}$ stress decreased the ratio of AsA/DHA, which was due to the oxidative stress induced by $\mathrm{Cr}$ stress. It has been reported that pretreatment with $\mathrm{LaCl}_{3}$ increased the activities of APX and GR in Saussurea involucrate Kar. et Kir. under salt stress ( $\mathrm{Xu}$ et al. 2007). In present study, we also found that pretreatment with $\mathrm{LaCl}_{3}$ increased the activities of APX and GR in the chloroplasts of maize, which was consistent with previous study concerning salt tolerance. Besides, we also showed that $\mathrm{LaCl}_{3}$ increased the activities of DHAR and MDHAR in the chloroplasts under $\mathrm{Cr}$ stress. Above results of our study suggested that pretreatment with $\mathrm{LaCl}_{3}$ could increase the ratios of AsA/ DHA and GSH/GSSG through the recycling pathway of AsA and GSH under Cr stress.

In our previous study, we found that $\mathrm{LaCl}_{3}$ could improve the cadmium tolerance of maize seedlings by enhancing the biosynthetic and recycling metabolism of ascorbate and glutathione (Dai et al. 2017). In this study, we also found that $\mathrm{LaCl}_{3}$ could improve the $\mathrm{Cr}$ tolerance of maize seedlings by enhancing the recycling metabolism of ascorbate and glutathione through enzymes APX, GR, DHAR, and MDHAR in the ascorbate-glutathione cycle 
at the chloroplast level. However, whether $\mathrm{LaCl}_{3}$ regulates the biosynthetic metabolism of ascorbate and glutathione is still unknown. Therefore, it will be interesting to investigate the role of $\mathrm{LaCl}_{3}$ in regulating the biosynthetic metabolism of ascorbate and glutathione in maize under $\mathrm{Cr}$ stress. Besides, we found that $\mathrm{LaCl}_{3}$ could improve the biomass of maize seedlings under both $\mathrm{Cd}$ and $\mathrm{Cr}$ stresses, which indicated that $\mathrm{LaCl}_{3}$ can be used a regulator in the $\mathrm{Cd}$ or $\mathrm{Cr}$ resistance cultivation of maize crops.

In conclusion, our results suggested that $\mathrm{LaCl}_{3}$ upregulated the antioxidant capacity in the chloroplasts of maize seedlings by increasing the activities of antioxidant enzymes and the ratios of AsA/DHA and GSH/GSSG, which protected the function of photosynthetic apparatus against $\mathrm{Cr}$ stress. These results provide new knowledge for the role of $\mathrm{La}$ in regulating the antioxidant mechanism in chloroplast of plants in response to Cr stress.

\section{References}

Bradford M.M.: A rapid and sensitive method for the quantitation of microgram quantities of protein utilizing the principle of protein-dye binding. - Anal. Biochem. 72: 248-254, 1976.

Brennan T., Frenkel C.: Involvement of hydrogen peroxide in the regulation of senescence in pear. - Plant Physiol. 59: 411-416, 1977.

Dai H., Shan C., Zhao H. et al:: Lanthanum improves the cadmium tolerance of Zea mays seedlings by the regulation of ascorbate and glutathione metabolism. - Biol. Plantarum 61: 551-556, 2017.

Dalton D.A., Russell S.A., Hanus F.J. et al.: Enzymatic reactions of ascorbate and glutathione that prevent peroxide damage in soybean root nodules. - P. Natl. Acad. Sci. USA 83: 3811$3815,1986$.

Giannopolitis C.N., Ries S.K.: Superoxide dismutases occurrence in higher plants. - Plant Physiol. 59: 309-314, 1977.

Grace S.C., Logan B.A.: Acclimation of foliar antioxidant systems to growth irradiance in three broad-leaved evergreen species. - Plant Physiol. 112: 1631-1640, 1996.

Griffith O.W.: Determination of glutathione and glutathione disulfide using glutathione reductase and 2-vinylpyridine. Anal. Biochem. 106: 207-212, 1980.

Guo B., Xu L., Guan Z. et al.: Effect of lanthanum on rooting of in vitro regenerated shoots of Saussurea involucrata Kar. et
Kir. - Biol. Trace Elem. Res. 147: 334-340, 2012.

He Z.Q., Zou Z.R., He C.X.: Effect of AMF on GSH-Px activity and cell membrane osmosis of tomato. - J. Northwest SciTech. Univ. of Agri. and For. (Nat. Sci. Ed.) 34: 53-57, 2006.

Heath R.L., Packer L.: Photoperoxidation in isolated chloroplasts. I. Kinetics and stoichiometry of fatty acid peroxidation. Arch. Biochem. Biophys. 125: 189-198, 1968.

Hodges D.M., Andrews C.J., Johnson D.A. et al.: Antioxidant compound responses to chilling stress in differentially sensitive inbred maize lines. - Physiol. Plantarum 98: 685692,1996

Huang G., Wang L., Zhou Q.: Lanthanum (III) regulates the nitrogen assimilation in soybean seedlings under ultraviolet-B radiation. - Biol. Trace Elem. Res. 151: 105-112, 2013.

Liu R.Q., Xu X.J., Wang S. et al.: Lanthanum improves salt tolerance of maize seedlings. - Photosynthetica 54: 148-151, 2016.

Ma J., Lv C., Xu M. et al:: Photosynthesis performance, antioxidant enzymes, and ultrastructural analyses of rice seedlings under chromium stress. - Environ. Sci. Pollut. Res. 23: 1768-1778, 2016.

Mahmud J.A.L., Hasanuzzaman M., Nahar K. et al.: $\gamma$-aminobutyric acid (GABA) confers chromium stress tolerance in Brassica juncea L. by modulating the antioxidant defense and glyoxalase systems. - Ecotoxicology 26: 675-690, 2017.

Miyake C., Asada K.: Thylakoid-bound ascorbate peroxidase in spinach chloroplasts and photoreduction of its primary oxidation product monodehydroascorbate radicals in thylakoids. - Plant Cell Physiol. 33: 541-553, 1992.

Nakano Y., Asada K.: Hydrogen peroxide is scavenged by ascorbate specific peroxidase in spinach chloroplasts. - Plant Cell Physiol. 22: 867-880, 1981.

Wang H., Feng T., Peng X. et al.: Up-regulation of chloroplastic antioxidant capacity is involved in alleviation of nickel toxicity of Zea mays L. by exogenous salicylic acid. Ecotoxicol. Environ. Safe. 72: 1354-1362, 2009.

Xu C.M., Zhao B., Wang X.D. et al:: Lanthanum relieves salinity-induced oxidative stress in Saussurea involucrate. Biol. Plantarum 51: 567-570, 2007.

Zhang L., Yang T., Gao Y. et al.: Effect of lanthanum ions $\left(\mathrm{La}^{3+}\right)$ on Ferritin-regulated antioxidant process under PEG stress. Biol. Trace Elem. Res. 113: 193-208, 2006.

Zhou J., Fang L., Li X. et al.: Jasmonic acid (JA) acts as a signal molecule in $\mathrm{LaCl}_{3}$-induced Baicalin synthesis in Scutellaria baicalensis seedlings. - Biol. Trace Elem. Res. 148: 392-395, 2012.

(C) The authors. This is an open access article distributed under the terms of the Creative Commons BY-NC-ND Licence. 